\title{
Desain dan Implementasi E-Commerce Berbasis Content Management System dengan Business Model Canvas pada Maen Vape Store
}

\author{
Samsinar ${ }^{* 1}$, Raditya Hadi Santoso ${ }^{* 2}$ \\ *Fakultas Teknologi Informasi, Universitas Budi Luhur \\ Jl. Raya Ciledug, Petukangan Utara, Kebayoran Lama, Jakarta Selatan \\ ${ }^{1}$ samsinarabudiluhur.ac.id \\ ${ }^{2}$ radityahadi7171@gmail.com
}

\begin{abstract}
Abstrak
Maen Vape Store adalah sebuah usaha di bidang lifestyle yang berdiri sejak tahun 2017 yang berada di Kota Tangerang. Maen Vape Store melayani komunitas pengguna vape dengan menyediakan alat-alat kebutuhan vape serta melayani penggantian kapas dan pemasangan kawat. Permasalahan yang dihadapi sekarang yaitu masih melakukan penjualan secara langsung, dimana konsumen harus datang langsung ke toko untuk membeli liquid dan aksesorisnya. Ditambah lagi wabah virus Corona Covid-19 yang merebak di Indonesia sehingga masyarakat diwajibkan untuk menerapkan pembatasan sosial berskala besar (PSBB) dengan tetap berada dirumah dan menghindari tempat tempat umum sehingga pelanggan yang datang untuk melakukan transaksi pembelian ataupun berkunjung menjadi sedikit. Berdasarkan kendala tersebut, maka penulis mencoba membangun website e-commerce berbasis Content Management System (CMS). Metode yang digunakan adalah Business Model Canvas serta pengumpulan data dilakukan dengan observasi, wawancara, analisa dokumen, dan studi literatur. Dengan adanya website ini, pemasaran produk lebih efektif, pelanggan mudah bertransaksi secara online, data pesanan tersimpan baik, penjualan meningkat, dan informasi ditampilkan menjadi lebih informatif.
\end{abstract}

Kata kunci: BMC, Penjualan Online, Vape, WordPress

\section{E-Commerce Design and Implementation Based on Content Management System using Business Model Canvas in a Maen Vape Store}

\begin{abstract}
Maen Vape Store is a lifestyle business established since 2017 located in Tangerang City. Maen Vape Store serves the vape user community by providing vape needs tools as well as serving cotton replacement and wire installation. The problem now is that it still does sales directly, where consumers have to come directly to the store to buy liquids and accessories. In addition, the covid-19 coronavirus outbreak that is spreading in Indonesia so that people are required to apply large-scale social restrictions (PSBB) by staying at home and avoiding public places so that customers who come to make purchase transactions or visit become few. Based on these constraints, the author tries to build an e-commerce website based on content management system (CMS). The methods used are Business Model Canvas as well as data collection conducted with observation, interview, document analysis, and literature studies. With this website, product marketing is more effective, customers are easy to transact online, order data is well stored, sales increase, and report information becomes more informative.
\end{abstract}

Keywords: BMC, Online Sales, Vape, WordPress

\section{Pendahuluan}

Perkembangan yang pesat pada teknologi informasi sangat berpengaruh dalam kehidupan sehari hari. Baik kehidupan individu, sosial maupun yang terkait dalam dunia bisnis. Banyak pelaku bisnis yang memanfaatkan kemajuan teknologi sehingga mempermudah dalam memperoleh informasi untuk menunjang aktivitas bisnisnya. Pada era modern saat ini persaingan bisnis juga semakin ketat, pelaku bisnis dituntut untuk mencari cara yang inovatif dan kreatif. Salah satu media transaksi bisnis yang bisa dilakukan yaitu menggunakan aplikasi $e$ commerce [1]. Untuk itu itu dibutuhkan model bisnis yang dapat mampu memberikan penjelasan bagaimana suatu 
bisnis mendapatkan atau mencapai keuntungan dan mengetahui siapa pelanggan bisnis tersebut [2].

Maen Vape Store ini merupakan salah satu usaha yang bergerak dibidang penjualan, khususnya penjualan vape. Penjualan merupakan kegiatan yang dilakukan oleh penjual dalam menjual barang atau jasa dengan harapan akan memperoleh laba dari adanya transaksi-transaksi tersebut dan penjualan dapat diartikan sebagai pengalihan atau pemindahan hak kepemilikan atas barang atau jasa dari pihak penjual ke Pembeli [3]. Pada Maen Vape Store terdapat permasalahan yang dihadapi, salah satunya yaitu, media pemasaran yang digunakan saat ini kurang efektif, karena masih mengandalkan spanduk toko dan sosial media Instagram yang hanya sebagai katalog saja sehingga pemasaran produk dirasakan kurang luas untuk diketahui masyarakat.

Maen Vape Store adalah salah satu toko vape yang masih melakukan penjualan secara langsung, dimana konsumen harus datang langsung ke toko untuk membeli liquid dan aksesorisnya. Pemasaran produk pada toko ini selain menggunakan spanduk ditoko. Ditambah lagi wabah virus corona Covid-19 yang merebak di Indonesia akhir-akhir ini berdampak negatif terhadap aktivitas bisnis Pemerintah juga menghimbau kepada seluruh masyarakat untuk tinggal dirumah dan menghindari tempat tempat umum dan pemilik toko juga dihimbau oleh Pemerintah setempat agar tutup lebih cepat sehingga waktu operasional terbatas dan pelanggan yang datang untuk melakukan transaksi pembelian ataupun berkunjung menjadi sedikit. Maka dari itu untuk mengatasi permasalahan tersebut, e-commerce bisa menjadi solusi untuk meningkatkan penjualan dan diharapkan penjualan menjadi lebih mudah dan efisien tanpa adanya kendala waktu operasional dan pelanggan bisa dengan mudah melakukan transaksi tanpa harus ke toko.

Pada penelitian ini penulis merujuk pada penelitian terdahulu dari [4] dengan judul "Perancangan ECommerce Untuk Mengembangkan Pemasaran Dan Pemesanan Produk Industri Kreatif Kerajinan Kayu". Penelitian ini mempunya permasalahan yaitu promosi yang dilakukan masih dari mulut ke mulut atau promosi dilakukan dari satu orang ke orang lain serta pembuatan katalog. Industri kreatif kerajinan kayu ini belum memanfaatkan internet sebagai salah satu media promosi untuk dapat membantu memperluas jaringan promosi produk sehingga UD. Tohu Srijaya sulit dalam meningkatkan penjualan Metode penelitian yang digunakan adalah wawancara dan mengunakan kuesioner. Selain itu peneliti menggunakan tahapan System Development Life Cycle (SDLC) yang terdiri dari perencanaan, analisa sistem, perancangan, implementasi dan pengujian prototype sistem dalam metode pengembangan sistemnya. Teknologi yang digunakan dalam penelitian ini menggunakan CMS (Content Management System) Wordpress dan menggunakan fasilitas Search Engine Optimization (SEO) untuk membantu pembeli dalam melakukan pencarian yang terdapat di mesin pencari. Dalam penelitian ini diharapkan dapat membantu memperluas jangkauan pemasaran produk dan dapat memungkinkan pembeli untuk mengakses website kapan saja dan dapat melakukan pemesanan dimana saja.

Penelitian terdahulu lainnya [5] yang berjudul "Sistem Informasi Penjualan Online (E-Commerce) Menggunakan CMS Wordpress Pada Toko Soraya Shop Dengan Menerapkan Metode RAD". Penelitian ini mempunyai permasalahan dimana proses penjualannya yaitu pelanggan datang langsung ke toko dan sistem penjualan yang masih dilakukan secara manual, transaksi yang masih dilakukan secara manual yang. Akibatnya admin sulit dalam mengolah data penjualan dan kesulitan dalam meningkatkan penjualan karena cukup ketatnya persaingan. Metode yang digunakan dalam penelitian ini adalah wawancara, observasi dan studi pustaka. Selain itu peneliti menggunakan Rapid Application Development (RAD) sebagai metode pengembangannya untuk membangun E-commerce berbasis CMS (Conten Management System) Wordpress. Dalam penelitian ini diharapkan dapat meningkatkan penjualan dan hubungan dengan pelanggan yang memungkinkan terciptanya kesetian pelanggan bukan hanya pada produknya namun juga setia terhadap perusahaan.

Penelitian lain oleh [6] dengan judul "Penerapan ECommerce Berbasis Website Untuk Media Promosi Pada Rock Guitar Instrument". Penelitian ini mempunyai permasalahan yakni Rock Guitar Instrument hanya dikelola oleh 2 orang, seorang sebagai luthier dan seorang sebagai marketing. Luthier bertugas membuat/ melakukan service gitar, sedangkan marketing bertugas mempromosikan produk. Hal ini dikarenakan hanya ada 1 marketing yang juga sering ikut melakukan tugas sebagai luthier. Marketing yang harusnya bisa fokus untuk mempromosikan produk ke masyarakat luas terpaksa ikut serta dalam pembuatan dan service gitar dari pelanggan. Akibatnya, aktivitas promosi produk menjadi terganggu atau kurang diperhatikan. Metode yang digunakan dalam penelitian ini adalah wawancara, observasi dan studi pustaka. Teknologi yang digunakan dalam penelitian ini menggunakan CMS (Content Management System) Wordpress dengan plugin WooCommerce. Dalam penelitian ini menghasilkan aplikasi E-commerce berbasis website untuk media promosi serta mitra dapat melakukan transaksi online dan pengelolaan website.

\section{Metodologi}

Pada penelitian ini metodologi penelitian yang digunakan yaitu:

\section{A. Metode Pengumpulan Data}

Dalam sebuah penelitian hal yang harus tersedia yaitu data dan informasi, yang kemudian diolah menjadi sistem yang dibutuhkan, hal tersebut diperoleh dengan beberapa cara sebagai berikut:

Wawancara: Metode ini dilakukan dengan cara menyampaikan sejumlah pertanyaan dari pewawancara untuk dijawab oleh narasumber Pemilik Maen Vape Store untuk mendapatkan suatu informasi.

Observasi: Metode ini digunakan dengan cara pengamatan secara langsung setiap proses berjalalan agar 
menemukan informasi dan pengetahuan yang diperlukan untuk bahan penelitian pada Maen Vape Store.

Analisis Dokumen: Teknik ini merupakan Teknik yang dilakukan dengan cara mengumpulkan dokumen dokumen yang Terkait.

\section{HASIL DAN PEMBAHASAN}

Bisnis penjualan alat-alat vape atau rokok elektrik cukup banyak dan meningkat dengan melihat tren konsumen Remaja maupun dewasa sejak tahun 2017 hingga saat ini, persaingan dalam usaha sejenis cukup ketat baik di toko-toko konvensional maupun online. Dalam hal ini Maen Vape Store melakukan pengembangan untuk penjualan produk dan menganalis model bisnis menggunakan Business Model Canvas $(B M C)$.

$B M C$ merupakan model untuk menganalisis permasalahan dan kebutuhan pada Maen Vape Store juga sebagai alat yang digunakan untuk menggambarkan, memvisualisasikan, menilai dan mengubah model bisnis yang ada saat ini dengan 9 blok elemen [8].

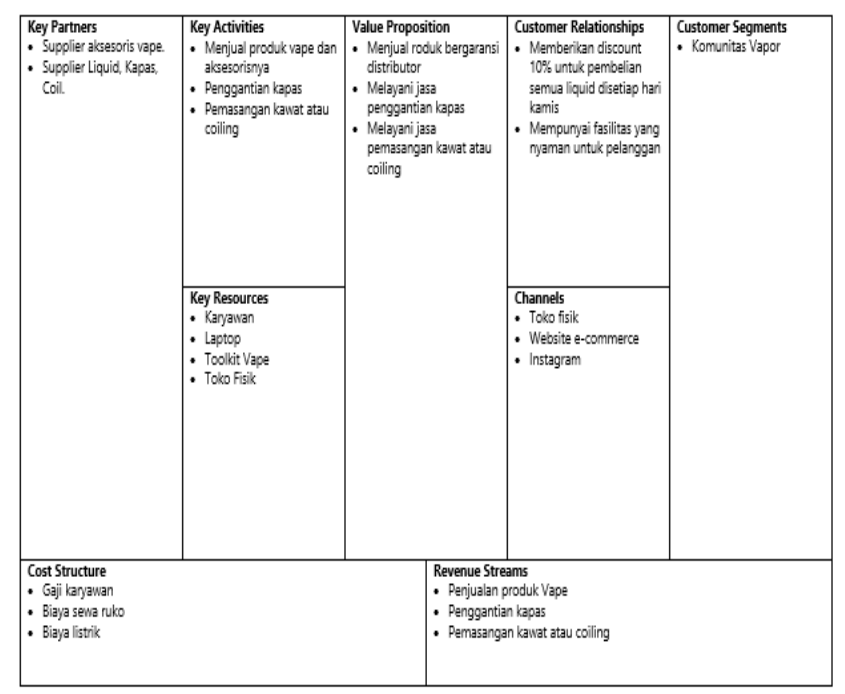

Gambar 1. Business model canvas

Pada Gambar 1, BMC yang terdiri dari 9 blok elemen yaitu:

1) Key Partners: Dalam elemen Key Partners, Maen Vape Store bekerja sama dengan Supplier untuk mensupplai alat kebutuhan vape seperti vape, 28 liquid, kapas, serta aksesoris vape dan penyedia tempat dimana Maen Vape Store bertempat.

2) Key Activities: Dalam elemen Key Activities, aktivitas yang dilakukan oleh Maen Vape Store adalah menjual produk vape dan akesorisnya, memberikan jasa penggantian kapas dan pemasangan kawat atau coiling.

3) Key Resources: Dalam elemen Key Resources, halhal yang dibutuhkan Maen Vape Store dalam menjalankan bisnisnya adalah karyawan, laptop, toolkit vape dan toko fisik.
4) Value Proposition: Dalam elemen Value Proposition, Maen Vape Store menjual produk yang memiliki garansi distributor. Selain itu juga melayani jasa penggantian kapas serta melayani jasa pemasangan kawat atau coiling untuk pelanggan.

5) Customer Relationship: Dalam elemen Customer Relationships, Maen Vape Store melakukan strategi agar pelanggan tetap datang ke toko dan loyal dengan cara memberikan discount $10 \%$ untuk pembelian semua liquid khusus dihari kamis dan mempunyai fasilitas yang nyaman untuk pelanggan.

6) Channels: Dalam elemen Channels, Maen Vape Store memanfaatkan media sosial instagram, toko fisik, website e-commerce, dan email.

7) Custumer Segment: Dalam elemen Key Partners, Maen Vape Store bekerja sama dengan Supplier untuk mensupplai alat kebutuhan vape seperti vape, 28 liquid, kapas, serta aksesoris vape dan Dan penyedia tempat dimana Maen Vape Store bertempat.

8) Cost Structure: Dalam elemen Cost Structure, Maen Vape Store mengeluarkan biaya yang diperlukan seperti biaya gaji karyawan, internet, listrik, biaya sewa ruko, hosting dan domain.

9) Revenue Streams: Dalam elemen Revenue Streams, Maen Vape Store mendapatkan keuntungan (profit) dari penjualan vape dan aksesoris, penjualan liquid, jasa penggantian kapas dan pemasangan kawan atau coiling.

Pada tahap Implementasi sistem e-commerce ini, didesain sudah melalui tahapan sebelumnya analisis model bisnis dalam Business Model Canvas. Alur Sistem Maen Vape Store dianalisis dan digambarkan dengan Activity Diagram dan Use Case Diagram.

\section{A. Activity Diagram}

Activity Diagram yaitu menggambarkan keseluruhan proses yang terjadi dan menggambarkan aliran kerja aktivitas dari sebuah sistem atau proses bisnis yang ada perangkat lunak [9]. Berikut adalah alur bisnis pada Maen Vape Store:

1) Proses Pendaftaran: Pada proses Pendaftaran akun baru, pelanggan mengunjungi website Maen Vape Store kemudian pelanggan dapat mendaftar dengan cara klik menu my account lalu klik register. Kemudian pelanggan mengisi data seperti username, email address dan password di form register. Lalu, kilk tombol sign up maka sistem akan menyimpan data pelanggan. Seperti yang terlihat pada Gambar 2.

2) Proses Pemesanan: Pada proses pemesanan barang, pelanggan mengakses website Maen Vape Store maka pada halaman front-end akan muncul tampilan semua produk yang telah di upload oleh admin Maen Vape Store dimenu shop. Pelanggan memilih produk yang ingin dibeli, lalu pelanggan menentukan jumlah yang ingin dibeli. Pelanggan klik add to cart kemudian produk akan tersimpan kedalam cart dan pelanggan dapat mengklik menu cart atau icon keranjang maka akan muncul produk yang telah dipilih pelanggan. Jika, 
pelanggan ingin menambahkan produk yang lain maka proses yang dilakukan sama dengan sebelumnya. Lalu, setelah pelanggan sudah selesai memilih produk dan ingin memesan maka pelanggan mengklik tombol proceed to checkout. Sistem akan mengecek status login pelanggan, jika pelanggan belum login maka pelanggan diharuskan login dahulu untuk melanjutkan proses checkout. Jika pelanggan sudah login di website Maen Vape Store pelanggan melanjutkan proses checkout dan setelah itu pelanggan mengisi form checkout seperti nama lengkap, provinsi, kota, kecamatan, alamat lengkap, kode pos, telepon, e-mail, catatan (optional) dan memilih kayanan ekspedisi pengiriman barang. Setelah pelanggan mengisi form checkout maka total pembayaran akan ditampilkan. Kemudian pelanggan klik tombol place order. Sistem akan menyimpan data order dan mengirim e-mail. Lalu pelanggan diarahkan ke halaman yang menampilkan bahwa pesanan berhasil dibuat beserta detail pesanan dan akun bank perusahaan untuk pelanggan melakukan pembayaran melalui transfer bank. Seperti yang terlihat pada Gambar 3.



Gambar 2. Activity diagram proses pendaftaran pelanggan baru

3) Proses Konfirmasi Pembayaran: Setelah pelanggan sudah melaukan pembayaran melalui transfer, pelanggan mengakses webiste Maen Vape Store dan login untuk melakukan konfirmasi pembayaran dan klik menu confirm payment, kemudian pelanggan mengisi form confirm payment seperti order number, nama pemilik rekening, tanggal transfer, jumlah transfer dan foto bukti transfer. Lalu klik tombol submit maka bukti pembayaran berhasil dikirim. Admin akan mengecek bukti pembayaran pelanggan yang masuk melalui e-mail atau admin dapat mengecek bukti pembayaran pelanggan yang masuk melalui menu confirm payment. Jika, bukti pembayaran salah pelanggan mengirim ulang bukti pembayaran, Jika bukti pembayaran benar, admin mengubah status order akan diubah menjadi processing, lalu admin memproses pesanan pelanggan. Seperti yang terlihat pada Gambar 4.

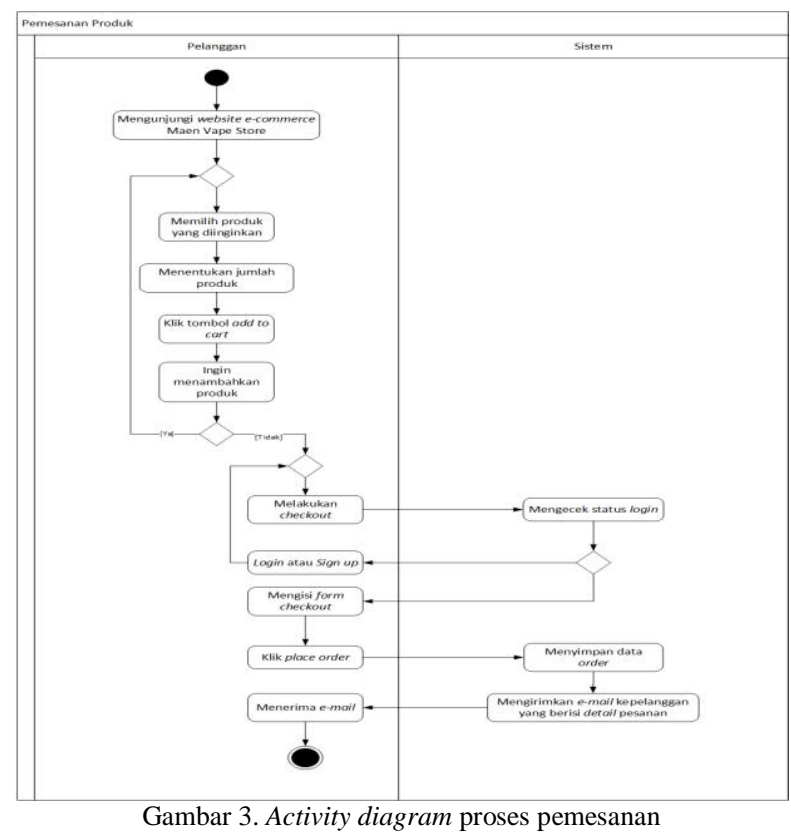

4) Proses Pengiriman: Pada proses pengiriaman, admin melakukan cek kondisi dan kelayakan produk yang akan dikirim sesuai pesanan, setelah itu admin melakukan packing produk lalu menyerahkan produk beserta alamat ke jasa pengiriman pihak ketiga yaitu JNE, lalu mendapatkan nomor resi pengiriman produk yang diperoleh. Kemudian admin input no resi dan mengubah status order menjadi updated tracking, lalu pelanggan menerima email tracking information updated dan pelanggan dapat melacak barang yang telah dikirim dengan klik tombol track dan menginput nomor resi. Seperti yang terlihat pada Gambar 5.

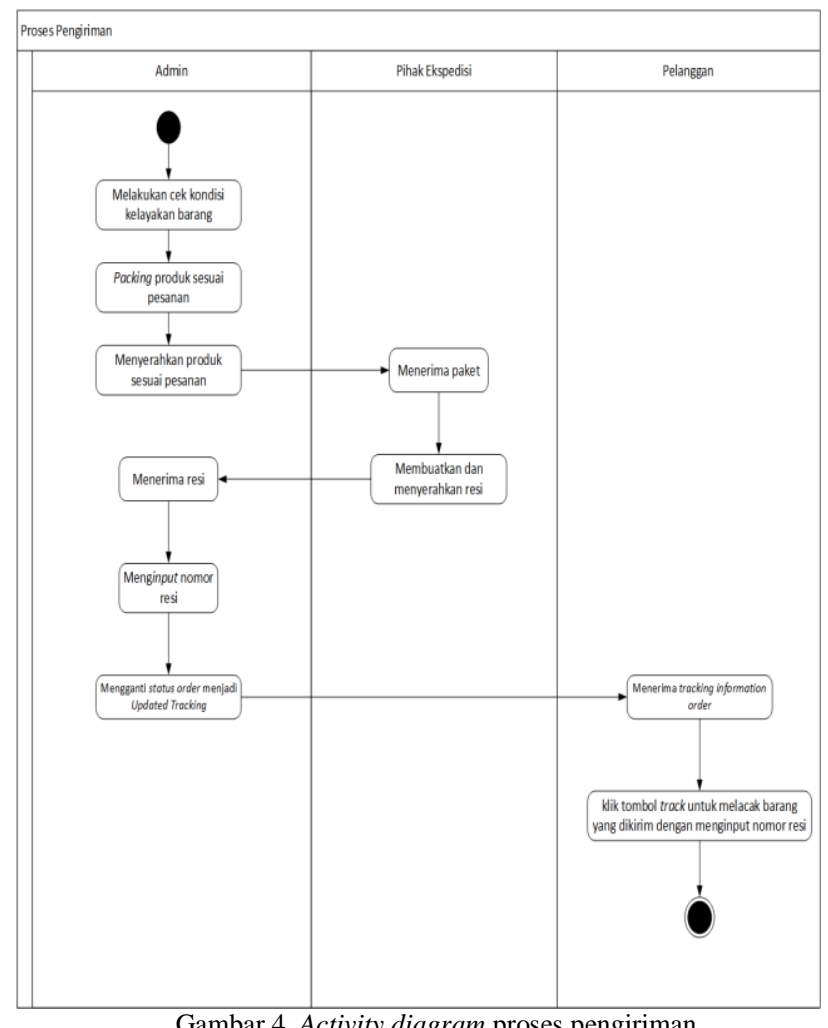


5) Proses Penerimaan: Pada proses penerimaan, saat barang yang dipesan pelanggan sudah diterima, maka pelanggan melakukan konfirmasi penerimaan barang melalui sistem dengan memilih menu konfirmasi penerimaan barang. Kemudian menginput data penerimaan barang. Lalu setelah selesai sistem otomatis menyimpan data dan mengirim email notifikasi penerimaan barang ke admin. Seperti yang terlihat pada Gambar 6.

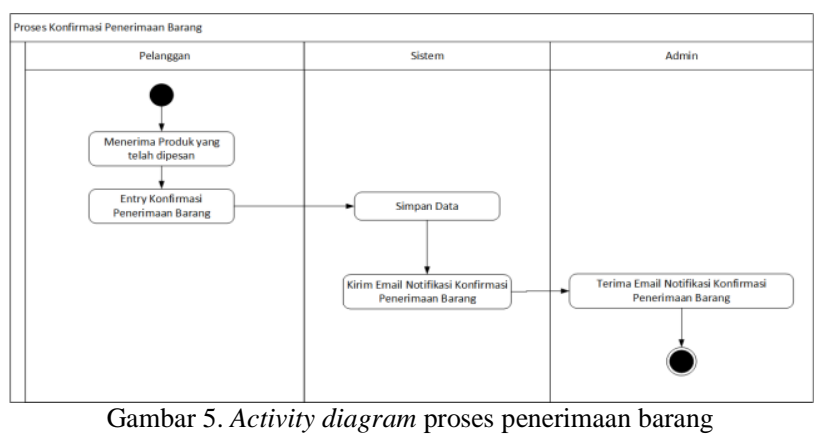

\section{B. Use Case Diagram}

Use Case Diagram yaitu yang mendeskripsikan interaksi satu atau lebih actor dengan sistem informasi yang dibuat untuk mengetahui fungsi apa saja yang ada Didalam senuah sistem dan siapa saja yang berhak menggunakan[10].

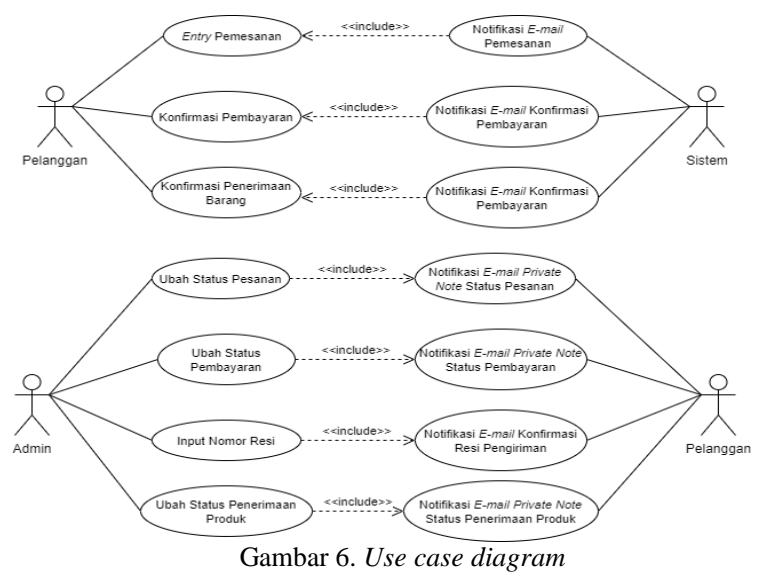

Pada Gambar 7, menggambarkan apa yang dilakukan oleh actor atau user dalam sistem e-commerce yaitu pemesanan, pembayaran, pengiriman barang dan penerimaan barang.

\section{Layout Interface}

Halaman Interface atau front-end adalah halaman dimana seluruh informasi yang dapat di akses oleh user pelanggan halaman web e-commerce:

Pada Gambar 8 merupakan tampilan halaman home atau halaman Utama dari e-commerce Maen Vape Store. Pada Gambar 9 merupakan tampilan halaman informasi detail produk. Pada Gambar 10 merupakan tampilan halaman konfirmasi pembayaran yang berisi informasi data input data konfirmasi pembayaran pelanggan.

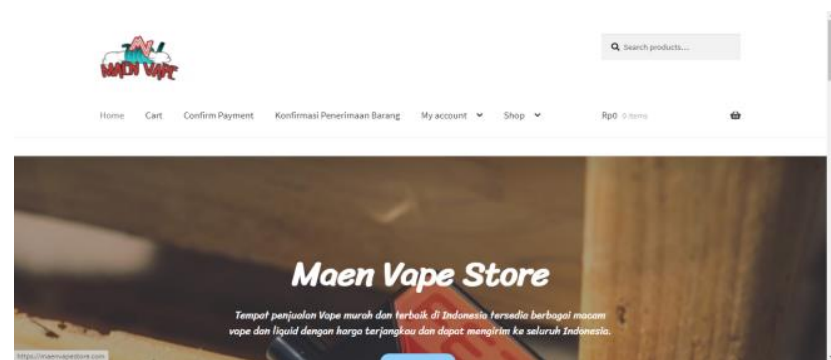

Gambar 7. Halaman Home Maen Vape Store
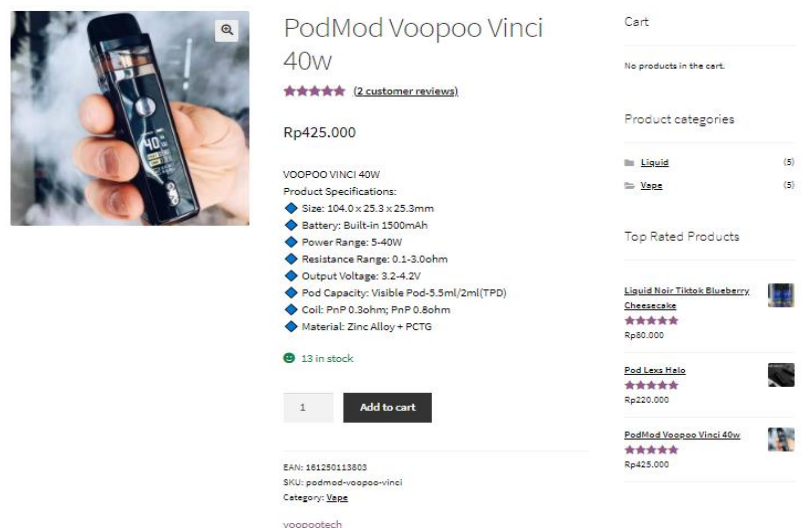

Gambar 8. Halaman Detail Produk

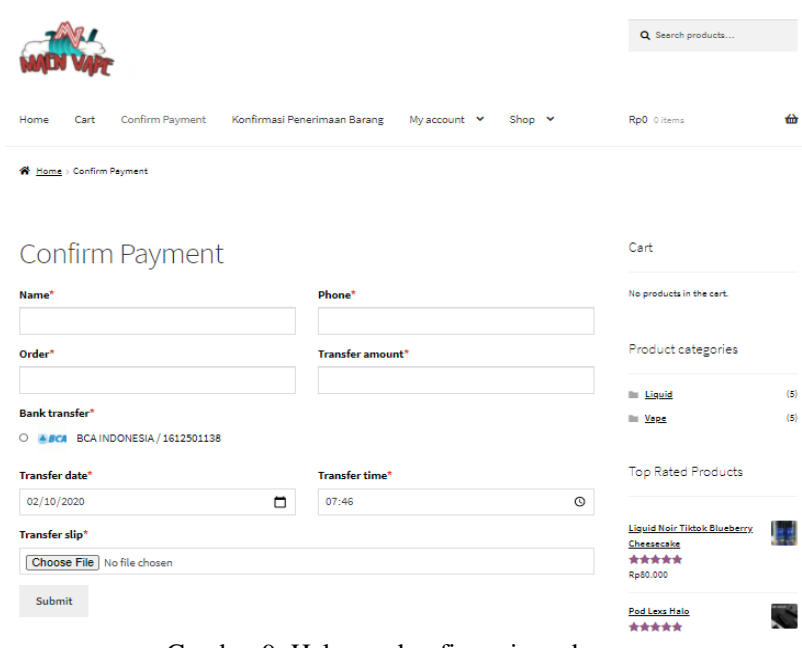

Gambar 9. Halaman konfirmasi pembayaran

\section{Seach Engine Optimization (SEO)}

Maen Vape Store menerapkan stragtegi SEO untuk mengoptimalisasikan website agar tampil di halaman pertama. Menurut [11] Search Engine Optimization (SEO) merupakan teknik untuk memaksimalkan suatu website agar lebih dikenal atau lebih mudah dibaca oleh search engine.

Untuk menjalankan SEO, membutuhkan sebuah plugins. Menurut [12] plugins adalah sebuah program tambahan yang bisa diintegrasikan dengan program utama agar memberikan fungsi tertentu yang tidak tersedia pada instalasi standart. Hasil dari Penerapan SEO pada web ECommerce Maen Vape Store dapat dilihat pada Gambar 11. 




Gambar 10. Search Engine Optimization

\section{KESIMPULAN}

Kesimpulan dari penelitian ini yaitu dengan adanya website E-Commerce dan didukung oleh media sosial instagram yang merupakan sumber traffic untuk website, lalu dengan adanya fitur newsletter pelanggan yang pernah membeli produk ada kemungkinan besar mereka akan membeli produk kembali, sehingga media pemasaran akan lebih efektif dan optimal, dengan adanya fitur yang disediakan pada e-commerce dapat mempermudah pelanggan dalam mendapatkan informasi dan melakukan proses transaksi yang tidak terbatasi oleh waktu dan admin dapat melihat secara berkala transaksi yang terjadi.

\section{DAFTAR PUSTAKA}

[1] S. P. Suryanto, T. J. Pattiasina, and A. Soetarmono, "Perancangan dan Pengembangan Toko Online dengan Metode Interaction Flow Modeling Language (Studi Kasus Toko Winata)," Teknika, vol. 6 , no. 1 , pp. 7-18, 2017.

[2] D. Adhitya and M. Eka, "Analisis Model Bisnis Pada BIsnis Sepatu Guten.IncMenggunakan Model Bisnis Kanvas," $J$. Sosioteknologi, vol. 15, no. 3, pp. 323-334, 2016.

[3] V. Sihombing, "Sistem Informasi Penjualan Mobil Suzuki Di Dealer Bagan Batu,” J. Sist., vol. 7, no. 2, pp. 113-119, 2018.

[4] E. Y. Arifianto, P. B. Santoso, and S. Kurniawati, "Perancangan E-Commerce Untuk Mengembangkan Pemasaran Dan Pemesanan Produk Industri Kreatif Kerajinan Kayu," in Seminar Nasional IENACO, 2018, pp. 575-582.

[5] D. Manulang, L. A. Abdillah, and Kurniawan, Sistem Informasi Penjualan Online (E-Commerce) Menggunakan CMS Wordpress Pada Toko Soraya Shop Dengan Menerapkan Metode RAD. 2017, pp. 7-12.

[6] H. Kurniawan, "Penerapan E-Commerce Berbasis Website Untuk Media Promosi Pada Rock Guitar Instrument," in Seminar Hasil Pegabdian Masyarakat, 2018, pp. 121-126.

[7] Z. Zamzuri, T. Wicaksono, and S. Karim, "Workshop Business Model Canvas untuk Analisa Bisnis Komprehensif," $J$. Panrita_Abdi, vol. 2, no. 2, pp. 105-112, 2018.

[8] M. Setijawibawa, "Evaluasi Model Bisnis Pada Perusahaan X Menggunakan Business Model Canvas," AGORA, vol. 3, no. 1, pp. 305-313, 2015.
[9] R. Gusriva, "Analisa Dan Perancangan Berorientasi Objek Pada Website Rencana Pengembangan Pendidikan Dasar Kota," J. KomTekInfo, vol. 4, no. 2, pp. 204-213, 2017.

[10] H. Hasanuddin, "Sistem Informasi Keuangan Dengan Metode Object Oriented Analisys Design," Technologia, vol. 7, no. 2, pp. 89-95, 2016.

[11] A. F. Sasatibi, A. F., Suharyono, \& Abdillah, Y. (2017). Analisis Pemanfaatan Search Engine Optimization Dalam Meningkatkan Penjualan Produk UKM Di Pasar Internasional (Studi Kasus Pada CV. Ayung Sportindo). Jurnal Administrasi Bisnis(JAB), 50(6), 96-105.tibi, Suharyono, and Y. Abdillah, "Analisis Pemanfaatan Search Engine Optimization Dalam Meningkatkan Penjualan Produk UKM Di Pasar Internasional (Studi Kasus Pada CV. Ayung Sportindo)," J. Adm. Bisnis(JAB), vol. 50, no. 6, pp. 96105, 2017.

[12] M. Fahrurrozi and Azhari SN, "Rancang Bangun Plugin Protégé Menggunakan Ekspresi SPARQL-DL Dengan Masukan Bahasa Alami," IJCSS (Indonesian J. Comput. Cyber Syst., vol. 11, no. 2, pp. 155-164, 2017. 